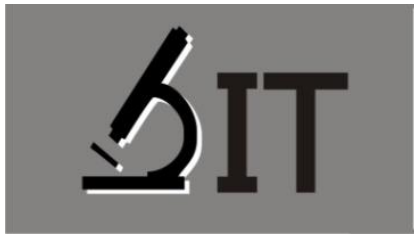

p-ISSN :2597-8977

e-ISSN :2597-8985

Rahmania*)

Prodi Pendidikan IPA FMIPA Universitas Negeri Makassar

Ramlawati

Prodi Pendidikan IPA FMIPA Universitas Negeri Makassar

Muhammad Aqil Rusli

Prodi Pendidikan IPA FMIPA Universitas Negeri Makassar
JIT 4 (1) (2020) 12-22

JURNAL IPA TERPADU

http://ojs.unm.ac.id/index.php/ipaterpadu

\section{PENGEMBANGAN MODUL IPA TERPADU BERBASIS KETERAMPILAN PROSES SAINS MATERI CAHAYA DAN OPTIK}

*) Correspondence Author: niadjaa@mail.com
Abstrak: Penelitian ini bertujuan untuk menghasilkan modul pembelajaran berbasis keterampilan proses sains yang valid, praktis, dan efektif. Subjek penelitian ini adalah peserta didik kelas VIII SMPN 1 Sungguminasa dengan jumlah 12 orang. Penelitian ini menggunakan model 4D Thiagarajan (Define, Design, Develop, Disseminate). Teknik pengumpulan data yang dilakukan yaitu dengan menggunakan instrumen lembar validasi ahli untuk menilai keavalidan, angket untuk menilai kepraktisan, dan tes untuk menilai keefektifan. Hasil penelitian menunjukkan bahwa penilaian pada tim ahli/pakar menunjukkan bahwa rata-rata skor perangkat tergolong valid dengan validasi konten bernilai 1 dari nilai maksimum 1. Hal ini berarti modul yang dikembangkan secara konseptual sudah layak untuk digunakan. Selanjutnya persentase hasil penilaian kepraktisan oleh pendidik menunjukkan kriteria sangat positif dengan persentase 92,8\% artinya pendidik dapat menggunakan dan menerima modul tersebut untuk digunakan dalam proses pembelajaran, begitupun dengan persentase hasil respons peserta didik terhadap modul yang dikembangkan menunjukkan kriteria sangat positif dengan persentase 92,3\% artinya peserta didik memberikan respons positif terhadap modul yang dikembangkan. Selanjutnya keterampilan proses sains yang dinilai dari hasil $\mathrm{N}$-gain terdapat $83,33 \%$ tergolong ke dalam kategori sedang. Hal ini menunjukkan terdapat peningkatan keterampilan proses sains. Berdasarkan hasil penelitian maka dapat disimpulkan bahwa modul IPA terpadu berbasis keterampilan proses sains memenuhi kriteria valid, praktis, dan efektif.

Kata Kunci: Modul IPA Terpadu, Keterampilan Proses Sains, Cahaya dan alat optik

\begin{abstract}
This study aims to produce a valid, practical, and effective science skill-based module. The subject of this research is the students of $8^{\text {th }}$ grade of Junior High School 1 Sungguminasa amounted to 12 students. This study uses the Thiagarajan 4D model (Define, Design, Develop, Disseminate). Data collection techniques carried out in this study were questionnaire techniques with expert validation sheet instruments, practicality sheets, and tests to assess effectiveness. From the research results, it is showed that testing on experts indicate that the average of modules device score is valid with validity content of 1 . It means that the conceptually developed modules are eligible for use. Furthermore, the percentage of the results of practicality assessment by teacher shows very positive criteria with percentage of $92,8 \%$ it means that teachers can use and accept the module to be used in the learning process, as well as the percentage of students' responses to the developed modules showing very positive criteria with percentage of $92,3 \%$ it means that students respond positively to the developed module. In addition, the
\end{abstract}


percentage of science process skills assessed from $\mathrm{N}$-gain result is $83,33 \%$ classified into medium category. It show improvement in science process skills. Based on the research results, it canbe concluded that the integrated module of natural science based on developed science process skills satisfies validity, practicality, and effectiveness criteria

Keyword: Integrated Science Module, Science Process Skills, Light and Optical Instrument 


\section{PENDAHULUAN}

Penyelenggaraan pendidikan sebagaimana yang diamanatkan dalam UU No.20 Tahun 2003 tentang Sistem Pendidikan Nasional diharapkan dapat mewujudkan proses berkembangnya kualitas pribadi peserta didik sebagai generasi penerus bangsa (Kemendikbud, 2015). Dalam sejarah perjalanan kemerdekaan, kurikulum pendidikan nasional telah mengalami sembilan kali perubahan dengan perubahan terbaru pada KTSP 2006 menjadi Kurikulum 2013. Perubahan tersebut merupakan konsekuensi logis dari terjadinya sistem politik, sosial budaya, ekonomi dan iptek dalam berbangsa dan bernegara.

Pendidikan ilmu pengetahuan alam (IPA) merupakan bagian dari pendidikan . Dalam pedoman kurikulum 2013 disebutkan bahwa pembelajaran IPA di tingkat SMP dilaksanakan dengan berbasis keterpaduan serta menekankan kompetensi pengetahuan, keterampilan, nilai dan sikap yang direfleksikan dalam kebiasaan berpikir dan bertindak. Konten IPA harus dibelajarkan secara terpadu karena salah satu manfaat pembelajaran terpadu yaitu pembelajaran dapat efisien dan efektif, karena beberapa kompetensi dasar dapat dicapai sekaligus (Depdiknas, 2005). Mengajarkan IPA secara terpadu tentu dibutuhkan pengajar yang berlatarbelakang IPA terpadu dan juga perangkat pembelajaran terpadu. Pembelajaran yang dilaksanakan harus memerhatikan dengan baik bahan ajar yang digunakan, karena pemilihan bahan ajar yang tepat dapat membantu dalam keberhasilan pembelajaran (Trianto, 2014).

Beberap hal yang belum optimal terjadi pada guru dalam penerapan IPA terpadu yaitu: 1) kesiapan guru, selama ini guru IPA berlatar belakang disiplin ilmu tersendiri yaitu fisika, biologi maupun kimia, 2) kesulitan memadukan konsep-konsep IPA menjadi suatu pembelajaran terpadu, 3) belum adanya buku ajar cetak yang memuat konsep-konsep IPA secara terpadu. Untuk itu, diperlukan perangkat pembelajaran IPA Terpadu sehingga sesuai dengan tuntutan kurikulum yang berlaku (Dewi, 2013).

Berdasarkan observasi di SMP Negeri 1 Sungguminasa yaitu dengan mengajukan pertanyaan pada guru dan peserta didik sesuai dengan analisis kebutuhan dalam mengumpulkan informasi. Pada sekolah tersebut pembelajaran IPA telah terlaksana, namun belum sepenuhnya sesuai dengan Kurikulum 2013. Adapun hal-hal yang kurang mendukung penerapan Kurikulum 2013 pada pembelajaran IPA Terpadu di sekolah tersebut yaitu perangkat pembelajaran yang tersedia masih kurang. Buku paket yang digunakan yaitu buku IPA Terpadu revisi 2014. Dimana dalam buku tersebut, materi yang tersaji masih kurang lengkap dan tidak terpadu. Selain itu, para pendidik IPAnya memiliki latar belakang pendidikan masing-masing fisika dan biologi, sehingga untuk mengajarkan materi IPA secara terpadu dibutuhkan perangkat pembelajaran IPA terpadu. Selain itu, buku paket yang digunakan di sekolah bukan milik pribadi peserta didik yang bisa digunakan kapan saja. Buku paket tersebut hanya digunakan saat pembelajaran berlangsung

Sesuai dengan paparan Kemendikbud, pada kurikulum 2013 ini peserta didik dituntut aktif dalam pembelajaran. Hasil studi TIMSS (Trends in International Mathematics and Science Study) 2015, menunjukkan (1) secara umum peserta didik Indonesia lemah di semua aspek konten maupun kognitif, baik untuk matematika maupun sains. Namun, diagnosa secara mendalam menemukan hal-hal yang sudah dikuasai juga hal-hal yang perlu mendapat perhatian lebih. (2) Peserta didik Indonesia perlu penguatan kemampuan mengintegrasikan informasi, menarik kesimpulan serta menggeneralisir pengetahuan yang dimiliki ke hal-hal yang lain. Jika ditinjau dari hasil PISA (Propgram for International Student Assesmen) 2015, dapat diketahui bahwa peserta didik masih lemah dalam kecakapan kognitif order tinggi (seperti menalar/ menganalisa/ mengevaluasi).

Hasil studi ini menunjukkan perlu ada perubahan orientasi kurikulum. Kurikulum 2013 pada pembelajaran IPA terpadu menganut sistem pembelajaran menjadikan peseta didik lebih terampil dan cakap, menguasai kompetensi afektif, kognitif dan psikomotorik, sehingga dibutuhkan keterlaksanaan pengajaran yang menyandang status terlaksananya pembelajaran secara konten 
untuk penguasaan kompetensi afektif, kognitif, dan psikomotorik. Salah satunya yaitu sistem belajar berbasis Keterampilan Proses Sains (KPS).

Mutrovina (dalam Mala, 2017) bahwa KPS peserta didik penting sekali untuk ditingkatkan dalam proses pembelajaran, karena KPS sendiri merupakan kompetensi dasar yang berguna untuk pengembangan sikap ilmiah dan pada akhirnya membentuk peserta didik kreatif, terbuka, dan inovatif.

Modul berbasis KPS perlu dikembangkan karena bahan pembelajaran yang ada kurang mendukung implementasi kurikulum 2013. Selain itu, berdasarkan dengan pemaparan sebelumnya diketahui beberapa kelebihan modul yang sangat mendukung keterlaksanaan. Pembelajaran. KPS itu sendiri merupakan semua keterampilan yang digunakan untuk memperoleh, mengembangkan dan menerapkan konsep, hukum, dan teori IPA, baik berupa keterampilan mental, fisik (manual) maupun sosial. Sehingga, KPS dapat menjadikan peserta didik mampu menerapkan metode ilmiah dalam memahami, mengembangkan dan menemukan ilmu pengetahuan.

Materi cahaya dan alat optik merupakan materi yang diajarkan oleh pendidik pada jenjang kelas VIII. Materi ini mengharuskan keterpaduan antara ketiga aspek IPA. Namun ketika pendidik mengajarkan materi tersebut pada setiap pertemuan masih cenderung mengajarkan satu aspek bidang studi. Seperti ketika mengajarkan bagian mata pendidik hanya terfokus ke aspek biologinya saja dan ketika mengajarkan tentang cahaya lebih terfokus ke fisikanya saja, padahal materi tersebut bisa diintegrasikan kedalam pembelajaran IPA secara terpadu. Sehingga dipandang perlu untuk mengembangkan bahan ajar seperti modul IPA Terpadu. Ada beberapa praktikum dalam materi pembelajaran ini, oleh karena itu menggunakan aspek keterampilan proses sains merupakan wadah yang tepat agar pembelajaran lebih bermakna.

Berdasarkan pernyataan latar belakang yang telah dipaparkan, peneliti akan mengembangkan modul IPA terpadu berbasis keterampilan proses sains pada materi cahaya dan alat optik dengan tujuan mengetahui validitas, kepraktisan dan keefektifan modul untuk meningkatkan keterampilan proses sains peserta didik kelas SMP kelas VIII.

\section{METODE}

Penelitian Educational Reseach and Development (R\&D) yang bertujuan untuk mengembangkan modul IPA terpadu berbasis keterampilan proses sains pada materi cahayadan alat optik. Model pengembangan perangkat pembelajaran yang digunakan adalah model Thiagarajan. Model Thiagarajan terdiri dari 4 tahap yang dikenal dengan model 4D (four D model). Keempat tahap tersebut adalah tahap pendefinisian (define), tahap perencanaan (design), tahap pengembangan (development) dan tahap penyebaran (disseminate). Adapun penelitian yang dilakukan masuk dibagian development.

Rumus yang digunakan untuk mengetahui validitas isi secara keseluruhan adalah formula Gregory (2007).

Tabel 1. Kontigensi kategori ulang dua ahli pada analisis Gregory

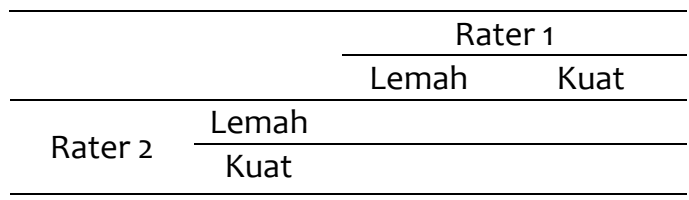


Tabel 2. Kontigensi untuk menghitung indeks Gregory

\begin{tabular}{lccc}
\hline & \multicolumn{2}{c}{ Rater 1 } \\
\cline { 3 - 4 } & & Lemah & Kuat \\
\hline \multirow{2}{*}{ Rater 2 } & Lemah & $\mathrm{A}$ & $\mathrm{B}$ \\
\cline { 2 - 4 } & Kuat & $\mathrm{C}$ & $\mathrm{D}$ \\
\hline
\end{tabular}

Analisis Gregory ditentukan dengan menggunakan rumus sebagai berikut:

$$
\text { Content validity }(C V)=\frac{D}{A+B+C+D}
$$

\section{Keterangan:}

A : jumlah item yang kurang relevan menurut kedua validator

B : jumlah item yang kurang relevan menurut validator I dan relevan menurut validator II

$C$ : jumlah item yang relevan menurut validator I dan tidak relevan menurut validator II

D : jumlah item yang relevan menurut kedua validator

Adapun analisis untuk menghitung persentase banyaknya pendidik dan peserta didik yang memberikan respons pada setiap kategori yang dinyatakan dalam lembar angket menggunakan rumus

$$
\mathrm{PRS}=\frac{A}{B} \times 100 \%
$$

Keterangan :

PRS: persentase respons pendidik/ peserta didk

A : jumlah skor perolehan pendidik/ peserta didik

$B$ : jumlah maksimal angket respons

Dengan kategori ditunjukan pada Tabel 3.

Tabel 3. Interpretasi Data Respons Pendidik/ Peserta Didik

\begin{tabular}{ll}
\hline Persentase Respons & Kriteria \\
\hline $80,1-100$ & Sangat Positif \\
$60,1-80$ & Positif \\
$40,1-60$ & Cukup Positif \\
$20,1-40$ & Kurang Positif \\
$0-20$ & Negatif \\
\hline & Sumber: Arikunto (2006)
\end{tabular}

Untuk mengetahui peningkatan hasil belajar yang terjadi sebelum dan sesudah penggunaan modul pembelajaran IPA terpadu berbasis keterampilan proses sains dihitung dengan menggunakan rumus gain ternormalisasi ( $\mathrm{N}$-gain) sebagai berikut:

$$
N-\text { gain }=\frac{\text { Spost }- \text { Spre }}{\text { Smaks-Spre }}
$$

Keterangan :

Spre : skor total pada tes awal hasil belajar peserta didik

Spost : skor total pada tes akhir hasil belajar peserta didik

Smaks : skor maksimum yang mungkin dicapai. 
Dengan menggunakan $\mathrm{N}$-gain tersebut maka dapat diketahui seberapa besar peningkatan hasil belajar peserta didik secara individual dan secara keseluruhan. Kriteria tingkat $\mathrm{N}$-gain dapat dilihat pada Tabel 4.

Tabel 4. Kategori Tingkat N-gain

\begin{tabular}{cc}
\hline Batasan & Kategori \\
\hline $\mathrm{g}<0,3$ & Rendah \\
$0,3 \leq \mathrm{g} \leq 0,7$ & Sedang \\
$\mathrm{g}>0,7$ & Tinggi \\
\hline
\end{tabular}

(Sumber: Hake, 1999)

\section{HASIL DAN PEMBAHASAN}

\section{Hasil}

Tahapan pertama yaitu define, tahap ini merupakan tahap untuk menetapkan dan mendefinisikan kebutuhan-kebutuhan pembelajaran dengan menganalisis tujuan dalam pengembangan pembelajaran. Berdasarkan hasil analisis awal akhir diperoleh informasi bahwa SMP Negeri 1 Sungguminasa menggunakan kurikulum 2013 sejak tahun 2016 sampai sekarang. Implementasi pembelajaran dengan menggunakan kurikulum 2013 di sekolah tersebut masih terdapat kendala yang ditemukan khususnya pada proses pembelajaran, dimana pendidik lebih aktif berbicara dalam menjelaskan materi, hal ini berdasarkan wawancara dari pendidik yang mengungkapkan bahwa peserta didik sulit memahami materi jika tidak dijelaskan secara keseluruhan. Dampak yang terjadi adalah peserta didik menjadi tidak aktif serta pembelajaran hanya fokus pada pemberian materi. Analisis ini juga berguna untuk menetapkan kompetensi dasar yang akan dikembangkan. Berikut ini hasil analisis kompetensi dasar pada materi cahaya dan alat optik yaitu KD 3.12 Menganalisis sifat-sifat cahaya, pembentukan bayangan pada bidang datar dan lengkung, serta penerapannya untuk menjelaskan proses penglihatan manusia, mata serangga, dan prinsip kerja alat optik. Kemudian KD 4.12 Menyajikan hasil percobaan tentang pembentukan bayangan pada cermin dan lensa

Kegiatan selanjutnya yaitu menelaah bahan ajar yang digunakan. Bahan ajar yang digunakan berupa buku paket yang dibagikan oleh kementrian pendidikan dan hanya buku itu, tidak ada bahan ajar lainnya lagi seperti modul. Dampaknya bahan ajar yang digunakan tersebut masih terdapat kekurangan dimulai dari pemberian materi yang hanya menekankan pada satu aspek pembelajaran yaitu fisika, kimia, atau biologi serta pengajaran masih terpusat pada pendidik.

Berdasarkan analisis awal tersebut menunjukkan bahwa permasalahan-permasalahan yang ditemui membuat proses pembelajaran menjadi tidak efektif, sehingga diperlukan solusi. Peneliti disini memberikan solusi untuk mengembangkan bahan ajar modul IPA yang dikemas secara terpadu. Pengembangan modul ini bertujuan untuk mengaktifkan peserta didik dalam pembelajaran dengan memasukkan kegiatan-kegiatan yang dapat melatih keterampilanketerampilan ilmiah peserta didik.

Analisis peserta didik dilakukan untuk mengetahui karakteristik peserta didik. Dalam proses pembelajaran pendidik harus menyesuaikan dengan karakteristik belajar peserta didik itu sendiri sehingga tujuan yang diinginkan dalam proses pembelajaran dapat tercapai. Kurikulum 2013 dalam silabus yang dikeluarkan oleh kementrian pendidikan dan kebudayaan menyebutkan proses pembelajaran IPA menggunakan metode ilmiah mengamati, merumuskan masalah, merumuskan hipotesis, melakukan percobaan, mengkomunikasikan, dan menyimpulkan. Peserta didik dalam proses pembelajaran sebelumnya pernah melakukan beberapa metode ilmiah di atas 
melalui kegiatan dalam modul pendidik, namun peserta didik kurang paham dalam melakukan kegiatan ilmiah tersebut, hal ini didapatakan melalui pemberian pertanyaan kepeserta didik mengenai cara penggunaan metode ilmiah, namun peserta didik tidak dapat menjelaskan proses tersebut dengan tepat, sehingga dalam kegiatan menggunakan metode ilmiah tersebut tidak sesuai dengan harapan yang diinginkan.

Analisis konsep dilakukan untuk mengidentifikasi, merinci dan menyusun secara sistematis konsep-konsep utama yang akan dipelajari peserta didik berdasarkan kurikulum 2013. Materi ajar yang dipilih pada penelitian ini adalah cahaya dan alat optikdengan empat tema utama yaitu, cahaya, cermin dan lensa, penglihatan dan alat optik.

Tahapan kedua yaitu designyang bertujuan untuk merancang perangkat pembelajaran. Pemilihan media dilakukan untuk mengidentifikasi media pembelajaran yang sesuai dengan karakteristik materi. Proses yang dilakukan pada pemilihan media yaitu menyesuaikan analisis tugas, analisis materi, karakteristik peserta didik dan fasilitas yang tersedia di sekolah. Adapun media yang digunakan adalah pemanfaatan sarana yang ada di laboratorium berupa KIT optik serta beberapa bahan yang terdapat di lingkungan sekitar peserta didik yang dibawa oleh peneliti untuk kegiatan praktikum pada setiap tema.

Pemilihan format disesuaikan dengan format yang diperlukan dalammodul. Sementara langkah pengembangan modul meliputi penulisan, pengadaptasian, pengeditan penelaahan modul yang dirancang. Langkah-langkah tersebut dilakukan dengan cara mengumpulkan bahan penulisan naskah yang terkait dengan materi yaitu berupa konsep, desain, dan gambar ilustrasi. Rancangan modul yang dibuat terlebih dahulu dikonsultasikan dengan pembimbing mengenai materi dan kegiatan-kegiatan yang akan dilakukan oleh peserta dididk, masukan yang diberikan akan menjadi bahan perbaikan dalam penyempurnaan modul yang dibuat.

Analisis tugas dilakukan untuk mengidentifikasikan keterampilan-keterampilan utama yang dilakukan peserta didik selama pembelajaran berdasarkan analisis konsep. Hasil analisis tugas ini bertujuan untuk membantu peserta didik untuk meningkatkan hasil belajar peserta didik dengan basis keterampilan proses sains.

Pada pengerjaan modul, peserta didik dititik beratkan dalam pengerjaan secara individu dengan begitu peserta didik akan berperan aktif dan tertarik sehingga motivasi belajarnya akan meningkat, begitu pula dengan hasil belajarnya. Dalam pengerjaan tugas juga terdapat beberapa kegiatan yang harus dikerjakan secara berkelompok, tugas ini didesain dengan cara peserta didik berdiskusi, hasil dari diskusi akan memberi jawaban masing-masing individu peserta didik sesuai dengan sudut pandangnya.

Tahapan ketiga adalah develope, pada tahap ini dilakukan tahapan validasi, uji coba terbatas dan uji coba kelas. Tahapan pengembangan ini bertujuan untuk menghasilkan sebuah produk modul IPA berbasis keterampilan proses sains yang sudah siap nantinya untuk disebarkan atau diujicobakan lebih luas lagi setelah dilakukan revisi sesuai dengan validasi dan revisi pada tahap uji coba. Produk berupa draf modul I divalidasi oleh 2 orang dosen ahli. Secara lengkap tersaji pada tabel 1. Setelah draf modul I divalidasi dan direvisi sesuai dengan saran para validator maka draf modul siap diujicobakan.

Tabel 5. Hasil Validasi Modul

\begin{tabular}{|c|c|c|c|}
\hline No. & Aspek Penilaian & Content Validity & Ket. \\
\hline 1. & Format & 1 & Valid \\
\hline 2. & Bahasa & 1 & Valid \\
\hline 3. & Isi & 1 & Valid \\
\hline 4. & Manfaat modul & 1 & Valid \\
\hline & Rata-rata total & 1 & Valid \\
\hline
\end{tabular}


Hasil validasi terhadap modul yang dikembangkan mempunyai nilai rata-rata 1 yang tergolong dalam kategori valid. Dinyatakan kategori valid apabila nilai hasil validasi berada pada nilai $\geq 0,75$.

Modul berbasis keterampilan proses sains kepraktisannya dinilai dari respons pendidik dan peserta didik menggunakan angket. Hasil analisis respons peserta didik dirangkum dalam Tabel 6.

Tabel 6. Rangkuman Hasil Respons Peserta Didik Terhadap Modul

\begin{tabular}{cllll}
\hline No & \multicolumn{1}{c}{ Presentase Respons } & & \multicolumn{1}{c}{ SPeserta Didik } & \multicolumn{1}{c}{ Interprestasi } \\
\hline 1 & $81-100$ & 12 & Sangat positif \\
2 & $61-80$ & 0 & Positif \\
3 & $41-60$ & 0 & Cukup positif \\
4 & $21-40$ & 0 & Kurang positif \\
5 & $<20$ & 0 & Tidak positif \\
\hline
\end{tabular}

Hasil analisis tersebut menunjukkan rata-rata persentase respons peserta didik berada dalam kategori 81 - 100 denganinterpretasi sangat positif.Hasil analisis respons pendidik dirangkum dalam Tabel 7.

Tabel 7. Rangkuman Hasil Respons Pendidik Terhadap Modul

\begin{tabular}{rlcl}
\hline No & Presentase Respons & \Pendidik & Interprestasi \\
\hline 1 & $81-100$ & 5 & Sangat positif \\
2 & $61-80$ & 0 & Positif \\
3 & $41-60$ & 0 & Cukup positif \\
4 & $21-40$ & 0 & Kurang positif \\
5 & $<20$ & 0 & Tidak positif \\
\hline
\end{tabular}

Analisis indikator tes keterampilan proses sains dengan perolehan skor perindikator pada saat pre test dan post test dengan menggunakan soal yang mewakili setiap indikator keterampilan proses sains meliputi mengamati, merumuskan masalah, merumuskan, melakukan percobaan, mengkomunikasikan, dan menyimpulkan. Tes keterampilan proses sains peserta didik dalam pengembangan moduldapat diketahui peningkatannya sesudah tes dengan persentase $\mathrm{N}$-gain.

Tabel 8. Persentase N-gain Keterampilan Proses Sains

\begin{tabular}{llcc}
\hline \multicolumn{1}{c}{ Nilai } & \multicolumn{1}{c}{ Kategori N-gain } & $\boldsymbol{\Sigma}$ & (\%) \\
\hline $\mathrm{g}>0,7$ & Tinggi & 2 & $16,66 \%$ \\
$0,3<\mathrm{g} \leq 0,7$ & Sedang & 10 & $83,33 \%$ \\
$\mathrm{~g} \leq 0,3$ & Rendah & 0 & $0 \%$ \\
\hline
\end{tabular}


Adapun pengelompokan data diatas dapat dilihat pada tabel 9 mengenai persentase pencapaian KPS perinidkator berikut:

Tabel 9. Persentase Pencapaian Keterampilan Proses Sains Peserta Didik Tiap Indikator

\begin{tabular}{clcc}
\hline No & \multicolumn{1}{c}{ Indikator } & N-gain & Kriteria \\
\hline 1 & Mengamati & 0,77 & Tinggi \\
2 & Merumuskan masalah & 0,69 & Sedang \\
3 & Merumuskan hipotesis & 0,54 & Sedang \\
4 & Merancang percobaan & 0,51 & Sedang \\
5 & Mengkomunikasikan & 0,60 & Sedang \\
6 & Menarik kesimpulan & 0,72 & Tinggi \\
\hline & Rata-rata & 0,63 & Sedang \\
\hline
\end{tabular}

\section{Pembahasan}

Setiap hasil penelitian harus dibahas. Pembahasan berisi pemaknaan hasil dan perbandingan dengan teori dan/atau hasil penelitian sejenis. Pada bagian ini tidak mengulang penyajian hasil penelitian tetapi menjabarkan diskusi hasil penelitian. Diketik dengan font Candara 11 pt spasi tunggal. Referensi ditulis dengan menngunakan caraAPA (APA Styles) dan semua referensi yang digunakan harus tercantum dalam daftar pustaka. Referensi yang digunakan adalah $80 \%$ dari jurnal nasional maupun internasional terbitan 10 tahun terakhir.Panjang paparan hasil dan pembahasan $40-60 \%$ dari total panjang artikel.

Berdasarkan hasil validasi modul yang dikembangkan berada pada kategori valid, sesuai yang dikemukakan oleh Direktorat Tenaga Kependidikan (2008), bahwa validasi modul bertujuan untuk memperoleh pengakuan atau pengesahan kesesuaian modul dengan kebutuhan sehingga modul tersebut layak dan cocok digunakan dalam pembelajaran. Validasi modul meliputi: isi materi modul; penggunaan bahasa; serta penggunaan metode instruksional. Sehubungan hal tersebut, maka modul yang dikembangkan mampu menjadi panduan peserta didik dalam pembelajaran IPA pada materi cahaya dan alat optik.

Pada kepraktisan modul, analisis yang dilakukan dengan persentase respons peserta didik dan pendidik yaitu jumlah skor perolehan dibagi jumlah maksimal angket respons dikali dengan persen. Maka diperoleh hasil analisis secara keseluruhan terhadap pengembangan modul yaitu hasil analisis tersebut ditunjukan dari rata-rata persentase respons peserta didik dan pendidik yaitu sangat positif dengan jumlah persentase peserta didik dan pendidik yaitu 92,3\% dan 92,8\% pada kategori sangat positif.

Kondisi ini memberikan gambaran bahwa modul IPA terpadu berbasis keterampilan proses sains sangat membantu peserta didik dalam belajar dan dapat dikatakan praktis. Hal tersebut sesuai dengan hasil penelitian Putri, dkk (2014) yaitu apabila rata-rata skor respons pendidik lebih atau sama dengan 3,25 dikonversi ke dalam kriteria kepraktisan perangkat pembelajaran, maka perangkat pembelajaran yang dikembangkan berada dalam kategori praktis.

Pada keefektifan modul diukur melalui tes yang diberikan kepada peserta didik untuk melihat seberapa besar peningkatan pencapaian keterampilan proses sains dari hasil perhitungan rata-rata $\mathrm{N}$-gain peserta didik yang berada pada skor 0.63 dengan kategori sedang. Nilai $\mathrm{N}$-gain tersebut menunjukkan terjadinya peningkatan pengetahuan keterampilan proses sains peserta didik setelah menggunakan modul IPA berbasis keterampilan proses sains yang dikembangkan. Hal ini sesuai dengan hasil penelitian Octavia (2015) bahwa Pengembangan modul IPA berbasis KPS ini dinilai efektif karena selain hasil belajar peserta didik yang meningkat, keterampilan proses sains dari peserta didik itu sendiri mengalami peningkatan. Jadi, dapat disimpulkan 
berdasarkan hasil diatas bahwa modul IPA terpadu berbasis keterampilan proses sains yang dikembangkan dapat meningkatkan keterampilan proses sains peserta didik.

Indikator pencapaian keterampilan proses sains yang terdiri atas 6 indikator menunjukkan hasil bahwa terdapat peningkatan keterampilan proses sains peserta didik dengan rata-rata kategori yaitu sedang. Adapun kegiatan mengamati kategori tinggi disebabkan karena pada modul, disajikan kegiatan pengamatan yang kontekstual seakan-akan lumrah peserta didik alami sehingga lebih antusias. Merumuskan masalah dan menuliskan hipotesis berada pada kategori sedang karena peserta didik sebelumnya belum pernah melakukan kegitan KPS tersebut selain dari penggunaan modul yang digunakan. Indikator yang memperoleh skor paling rendah yaitu merancang percobaan. Hal ini disebabkan karena pada proses pembelajaran berlangsung kegiatan yang dilakukan peserta didik melaksanakan kegiatan praktikum dengan langkah kegiatan yang tertera dalam modul, sehingga peserta didik tidak terlatih untuk merancang percobaan sendiri. Selanjutnya, kegiatan mengkomunikasikan dengan kategori sedang disebabkan karena dalam menganalisis data yang telah dikumpulkan, harapannya peserta didik memiliki jawaban masing-masing namun pelaksanaannya tetap dikomunikasikan sesama teman kelompok jadi akan ada jawaban yang sama, sehingga saat berhadapan dengan soal yang pada dasarnya menjawab sendiri, ada yang mampu dan ada yang keliru memecahkan sendiri. Kegiatan KPS yang terakhir yaitu menarik kesimpulan dengan kategori tinggi, hal ini disebabkan pada modul, arahan membuat kesimpulan telah dicantumkan sama halnya dengan kegiatan KPS lainnya. Bedanya KPS menyimpulkan pada tema pertama, menuliskan kesimpulan dengan bantuan pertanyaan sehingga dijadikan sebagai stimulus dan untuk tema berikutnya tanpa bantuan pertanyaan dengan harapan telah dapat menuliskan kesimpulan karena telah terlatih sebelumnya.

Berdasarkan analisis perhitungan $\mathrm{N}$-gain yang telah dilakukan, peningkatan keterampilan proses sains kategori tinggi sebanyak 2 orang dan kategori sedang sebanyak 10 orang. Berdasarkan hal tersebut dapat dikemukakan bahwa terjadi peningkatan signifikan keterempilan proses sains peserta didik. Hal ini sesuai dengan teori yang dikemukakan oleh Hake (dalam Sundayana, 2016) bahwa uji n-gain adalah uji yang bisa memberikan gambaran umum peningkatan skor hasil pembelajaran antara sebelum dan sesudah diterapkannya metode tersebut. jadi, dapat disimpulkan berdasarkan hasil diatas bahwa modul IPA terpadu berbasis keterampilan proses sains yang dikembangkan dapat meningkatkan keterampilan proses sains peserta didik.

\section{KESIMPULAN}

Berdasarkan hasil penelitian yang telah dilakukan pada peserta SMPN 1 Sungguminasa dapat ditarik kesimpulan bahwa modul yang dikembangkan valid, praktis dan efektif dalam meningkatkan keterampilan proses sains peserta didik pada materi cahaya dan alat optik.

\section{DAFTAR PUSTAKA}

Arikunto, S. (2006). Prosedur Penelitian Suatu Pendekatan Praktik. Jakarta : Rineka Cipta.

Depdiknas. (2005). Panduan Pengembangan Pembelajaran IPA Terpadu. Jakarta: Puskur Balitbang Depdiknas.

Dewi, K., Sadia, I W,.\& Ristiati, N.P. (2013). Pengembangan Perangkat Pembelajaran Ipa Terpadu dengan Setting Inkuiri Terbimbing Untuk Meningkatkan Pemahaman Konsep Dan Kinerja Ilmiah Siswa. E-Journal Program Pascasarjana Universitas Pendidikan Ganesha Program Studi Pendidikan IPA. Vol 3. 
Direktorat Tenaga Kependidikan Direktorat Jenderal Peningkatan Mutu Pendidik Dan Tenaga Kependidikan Departemen Pendidikan Nasional. (2008). Diakses Tanggal 13 Juli 2019. “IntrumenPengawasanSekolah”.http://file.upi.edu/direktori/fip/jur._administrasi_pendidika n/197205282005011-nur_aedi/4-25/materi_4.pdf

Gregory, R.J. (2007). Psychological Testing: History, Principles and Apllication. Boston: Pearson.

Hake, R. (1991). Analizing Change/Gain Scare. Diakses pada tanggal 28 Juli 2017.http://www.physis.indiana.edu/sdi/analyzingchangegain.pdf

Kementrian Pendidikan dan Kebudayaan. (2015). Dokumen Kurikulum 2013. Jakarta: Balitbang Depdiknas.

Mala, N.A., \& Widodo, W. (2017). Kelengkapan Media Dalam Pembelajaran IPA Serta Keterampilan Proses Sains Pada Siswa Kelas VIII SMP. E-Journal Pensa.Volume 05 Nomor 03.

Octavia, Friska Rosa. (2015). Pengembangan Modul Pembelajaran Ipa Smp Pada Materi Tekanan Berbasis Keterampilan Proses Sains. Jurnal Pendidikan Fisika. Vol. lii. No. 1.

Tamher, S. (2006). Hubungan antara Kelulusan Sipenmaru dengan Prestasi Belajar Mahasiswa Keperawatan Poltekkes Jakarta III. Diakses tanggal 3 Nopember 2011 darihttp://isjd.pdii.lipi.go.id/admin/jurnal/2106 924.pdf.

Thiagarajan, S., Semmel D.S dan Semmel M.I. (1974). Instructional Development for Training Teachers of Expectacional Children. Indiana: University Bloomington.

Trianto. (2014). Model Pembelajaran Terpadu. Jakarta : Bumi Aksara.

\section{Rahmania}

Guru SMP IT As-Sunnah Makassar, aktif melakukan penelitian pada bidang Pendidikan IPA, dapat dihubungi melalui email: niadjaa@gmail.com.

\section{Ramlawati}

Dosen Program Studi Pendidikan IPA FMIPA UNM, aktif melakukan penelitian pada bidang Pendidikan IPA, dapat dihubungi melalui email: ramlawati@unm.ac.id.

\section{Muhammad Aqil Rusli}

Dosen Program Studi Pendidikan IPA FMIPA UNM, aktif melakukan penelitian pada bidang Pendidikan IPA, dapat dihubungi melalui email: m.aqilrusli@gmail.com. 